This is a self-archived version of an original article. This version may differ from the original in pagination and typographic details.

Author(s): Leppäaho, Tanja; Pajunen, Kalle

Title: Institutional distance and international networking

Year: 2018

Version: Accepted version (Final draft)

Copyright: (C) 2017 Informa UK Limited, trading as Taylor \& Francis Group

Rights: In Copyright

Rights url: http://rightsstatements.org/page/lnC/1.0/?language=en

Please cite the original version:

Leppäaho, T., \& Pajunen, K. (2018). Institutional distance and international networking. Entrepreneurship and Regional Development, 30(5-6), 502-529.

https://doi.org/10.1080/08985626.2017.1407365 


\section{Institutional Distance and International Networking}

Tanja Leppäaho $(a, b)$ and Kalle Pajunen ( $b$ )

a) School of Business and Management Lappeenranta University of Technology Lappeenranta, Finland tanja.leppaaho@lut.fi

b) Jyväskylä University School of Business and Economics University of Jyväskylä Jyväskylä, Finland kalle.pajunen@jyu.fi

Final draft of the article published in:

Entrepreneurship and Regional Development, https://doi.org/10.1080/08985626.2017.1407365 


\title{
Institutional Distance and International Networking
}

\begin{abstract}
We focus on how small- and medium-sized enterprises (SMEs) adapt to differences in institutional logics (values, beliefs, and rules) in their networking when they enter an institutionally distant market. We address gaps in the literature, relating to the role of institutional logics in SME internationalization, and how institutional distance affects the formation of network ties. We show how the social interaction involved in internationalization is embedded in the institutional logics followed by partnering actors. Specifically, we demonstrate how institutional distance may constrain the networking activities of SMEs and identify practices that may support successful internationalization.
\end{abstract}

Keywords: networking; internationalization; institutional distance; institutional logics

\section{Introduction}

Every organization is embedded in a system of specific values, beliefs, and ideological assumptions. The cultural and material practices relating to such a system - which can be defined as its institutional logics - largely define how organizations and actors interpret their social surroundings (Thornton, Ocasio, and Lounsbury 2012). In the context of international business, a firm seeking to internationalize its operations to a foreign country will almost inevitably face a new institutional environment and local actors that follow certain logics of behavior based on certain cultural and material practices of that system. In other words, the internationalizing firm will experience the issue of institutional distance (Kostova and Zaheer 1999; Xu and Shenkar 2002), involving possibly multiple institutional logics.

Previous research has acknowledged that such institutional distance is likely to affect the operational decisions made by foreign firms (e.g. Salomon and Wu 2012). However, prior research has not specifically examined how a firm facing the issue of institutional distance and consequently, multiple institutional logics - is able to create and maintain business relationships and networks in the host country. We would argue that the networking activities 
of firms (involving for example the creation of strong, cohesive relationships, or alternatively, reliance on more formal, weaker, arms-length connections) are largely driven by the cognitive and normative prescriptions laid down by institutional logics. Thus, if the networking firms are from the same organizational field, and are embedded in the same institutional logic, they may be able to avoid major tensions deriving from the behavioral expectations related to creating and maintaining relationships. However, as suggested by previous research in the field of institutional theory (e.g. Dalpiaz, Rindova, and Ravasi 2016; Greenwood et al. 2011; Pache and Santos 2013), different and conflicting institutional logics are likely to generate behavioral tensions. In this paper, therefore, we examine the extent to which firms that experience institutional distance and the effects of multiple institutional logics may nevertheless be able to build and maintain network ties during the process of internationalization.

We addressed this issue via a study conducted on eight internationalizing Finnish smalland medium-sized enterprises (SMEs) in the manufacturing sector. These firms had their own logics of behavior, derived from their home country, and they had to adapt their networking behavior to fit the institutionally distant context of markets in France. Hence, our overarching research questions ran as follows: (i) How do SMEs adapt to differences in institutional logics when they enter an institutionally distant market? (ii) How do they develop, or fail to develop, network ties in such a market?

We observed that two out of eight case SMEs were able to understand and overcome different institutional logics. Subsequently, they allowed the French and Finnish institutional logics to co-exist, and created a cross-institutional consensus. These two case SMEs were also able to do more with their networks over time; thus, they were able to build stronger ties, and this gave space for building new ties. The other six SMEs experienced significant behavioral tensions related to institutional logics, and were therefore unable to develop either moderately strong ties or more numerous weak ties in the institutionally distant market. 
The paper contributes to actor-level research on institutional distance and the effects of multiple logics (e.g. Dalpiaz et al. 2016; Pache and Santos 2013) on the operational decisions of internationalizing SMEs by specifically demonstrating how institutional distance can affect the international networking activities.. In so doing, it adds to the existing literature on SME internationalization (e.g. Chetty and Wilson 2003; Coviello 2006; Ellis 2000, 2011; Harris and Wheeler 2005; Prashantham and Dhanaraj 2010; Slotte-Kock and Coviello 2010; Yli-renko, Autio, and Tontti 2002), and to literature on the development of network ties (NTs) over time (Anderson and Jack 2002; Gedajlovic et al. 2013; Hoang and Antoncic 2003; Jack and Anderson 2002; Jack, Dodd, and Anderson 2008; Johannisson 2000; McKeever, Anderson, and Jack 2014). In following this path, we also address the recent call of Delios (2017), who advocates detailed examination of the context surrounding firms' international activities.

\section{Theoretical Background}

\section{SME internationalization and networks}

The internationalization of SMEs can be approached from different theoretical perspectives, developed in different historical contexts. During the 1970s, the Uppsala model (Johanson and Vahlne 1977; Johanson and Wiedersheim-Paul 1975) was introduced to explain the slow internationalization process of firms. It can be considered valid for most SMEs, since a scarcity of resources makes such firms proceed incrementally. The network model of internationalization (Johanson and Mattsson 1988) was presented in the 1980s, when it became evident that firms used various networks to facilitate their internationalization activities. The network model proposes that a firm can compensate for its limited resources by developing its position in an existing network (i.e. building network closure, see Coleman 1988), or else by establishing new ties (i.e. bridging structural holes, see Burt 2000; Johanson and Mattsson 1988). Relevant here also is the International New Venture (INV) theory of Oviatt and 
McDougall (1994), which sought to explain why some firms were able to internationalize right after their inception, hence without following the incrementalism of the Uppsala model.

Internationalization research has accumulated during recent decades (see e.g. Chetty and Wilson 2003; Coviello 2006; Harris and Wheeler 2005; Oviatt and McDougall 2005); nevertheless, the network perspective on internationalization (Johanson and Mattsson 1988) remains valid in terms of its attention to the actor-level behavior and practices related to internationalization. Building on ideas suggested by Johansson and Mattsson (1988), researchers have observed that SMEs benefit from being a part of an extensive social network, because such a network brings them more opportunities that those available outside their existing network (Prashantham and Dhanaraj 2010; Yli-renko, Autio, and Tontti 2002). For his part, Ellis (2011) found personal-level ties to be of extreme importance in gaining knowledge of foreign markets. However, Prashantham and Dhanaraj (2010) emphasized that growth in social capital, though important, is not inevitable: social capital can also decline, or firms may become over-embedded with their collaborators, leading to conformist and outdated patterns of thinking, and a resulting decline in competitive advantage. In connection with this, Agndal and Chetty (2007) concluded that business relationships are more influential than social relationships in the strategy changes of SMEs. Furthermore, Coviello (2006) found that the foreign network ties possessed by an SME (an international new venture in this case) prior to internationalization were important, and that they seemed to consist of business ties more often than social ties.

\section{Institutional logics and networking behavior}

The cornerstone of institutional analysis is the idea that organizations are always embedded in specific institutional contexts; these create regularities and stability, and in so doing both constrain and enable organizational activities. According to Thornton and Ocasio $(1999,804)$, 
a core feature of any kind of institutional context is its institutional logic(s), definable as "the socially constructed, historical patterns of material practices, assumptions, values, beliefs, and rules by which individuals produce and reproduce their material subsistence, organize time and space, and provide meaning to their social reality." Seen in this light, logics offer guidelines on how to interpret and behave in social situations (Thornton and Ocasio 2008) - including those in which firms build network ties.

A firm that is embedded in a particular context usually takes the dominant institutional logic for granted. However, as recent literature has shown, in an interinstitutional context, firms may face logics which differ from the dominant one, with ensuing mutual incompatibility (e.g. Greenwood et al. 2011). Under the pressures of diverging institutional demands, firms may feel that they have to modify the kinds of attention structures and cognitive frames which largely determine how organizational actors make sense of their surroundings, and which define the appropriate activities and responses in social situations (Thorton, Ocasio, and Lounsbury 2012).

Despite this, as noted by Greenwood et al. (2011), research up to now has not adequately examined how firms may adopt particular types of activities in seeking to tackle different or competing logics. Firms may face institutional diversity in their existing area of business activity (e.g. Dalpiaz, Rindova, and Ravazi 2016). However, we suggest that the issue typically arises in the form of institutional distance, when firms extend their activities to other host countries. That is, when a firm encounters the local actors that are deeply embedded in the institutional environment the host country, with potentially divergent logics driving their attention, interpretation, and behavior.

Here, it is worth noting that research on institutional distances (Berry et al. 2010; Kostova and Zaheer 1999; Xu and Shenkar 2002) has already shown how dissimilarities between the institutional environments of host and home countries create fundamental legitimacy 
challenges for multinational firms. However, although extremely valuable, such country-level comparisons of institutional environments can sometimes be inadequate in capturing the challenges faced by firms entering new host countries. As O'Grady and Lane (1996) have demonstrated, even countries which are psychically close to each other, and which may initially be perceived as fairly similar (such as the USA and Canada), can actually be very different in terms of certain specific business, industry, and culture-related issues, and (in particular) how individuals make sense of these issues. Accordingly, we could suggest that an institutional logics approach provides a useful metatheoretical perspective when one is seeking to capture how the agentic behaviors of internationalizing firms are embedded in institutional contexts (cf. Thornton et al. 2012, Chapter 4). This may be of use in understanding how, in practice, internationalizing firms proceed in their attempts to deal with the issue of institutional distance.

Accordingly, the considerations above suggest that in order to explain why some SMEs are more successful in their internationalization activities than others, we should consider how these firms are able to adapt their networking behavior to the institutional context of the host country - a context that can both enable and constrain their activities. In this paper, in order to capture the variety of networking behaviors among SMEs in a theoretically meaningful way, we shall focus on three dimensions, namely structural holes (SHs), network closure (NC), and the strength of ties.

The core networking mechanisms that provide social capital can be seen as (i) the creation of structural holes (Burt 2000), and (ii) network closure (Coleman 1988). According to Burt (1992), the benefits of social capital derive from the diversity of information and the brokerage opportunities created by the lack of connections between separate groups in social networks. These structural holes (the gaps or lacunae in networks) permit a competitive advantage for a person (or firm) whose relationships span the holes. Individuals whose networks have only a limited number of SHs are aware of and have control over more 
rewarding opportunities. The relationships that act as bridges to other groups (such as firms) can result from events such as the setting up of cross-functional teams, inter-organizational conventions, or professional meetings that bring together people from different groups (Burt 2000). Network brokerage can also be indirect, if there is a strong link to a person/firm with a strong connection to someone else who is important for the firm (Burt 2010). This can be the case, for instance, if the foreign agent of the firm has strong relationships with customers who are completely unfamiliar to staff at headquarters.

Network closure (NC) is created by a network of strongly interconnected persons (Burt 2000). It emphasizes the positive effect of cohesive social ties in the creation of social capital. Hence, NC refers to networks in which everyone is connected in such a way that no one can escape the notice of others; in operational terms this usually means a dense network (Coleman 1988). Social norms are given "closure" when two or more individuals recognize that it is mutually advantageous to cooperate. In a closed network "people have strong relations with one another or can reach one another indirectly through strong relations to mutual contacts" (Burt 2010, 251). Closure facilitates access to information, because another person in the network can briefly convey what is essential; hence, knowledge sharing is efficient. Moreover, when people have strong relations in their network, they obtain more reliable communication channels. They also gain protection, since by means of their contacts they are better able to cooperate against someone who does not obey the network's norms (Burt 2000; Coleman 1988).

Although SHs and NC have been regarded as opposed to each other (e.g. Gargiulo and Benassi 2000), they can also been seen as complementary means of gaining social capital (Burt 2000; Podolny and Baron 1997). Thus, Burt (2000) found that the performance of a firm is optimal when the firm achieves high levels in both $\mathrm{NC}$ and the number of non-redundant contacts beyond the firm. Networks that span SHs may provide the manager with timely 
information on new opportunities, whereas cohesive ties are needed to exploit those opportunities (Podolny and Baron 1997). Furthermore, the formation of embedded ties (Gulati and Gargiulo 1999) - which may lead to NC - can be beneficial in an early phase of networking. Nevertheless, in a later phase, when organizational change is needed, the flexibility offered by SHs may be more important than NC.

A further important factor to consider is whether the social capital ties are strong or weak. According to Granovetter (1973), strong ties are associated with relationships which have developed through interaction over time, and which consequently encompass emotional intensity, intimacy, and reciprocal services. An individual can have only a certain number of strong ties, due to the maintenance costs associated with more intimate relationships (Singh 2000). By contrast, the number of weak ties can be high. These weak ties do not require high maintenance, but they can significantly assist the entrepreneur in accessing information. Granovetter (1973) argues that weak ties act as bridges to sources of information that are not necessarily contained within an entrepreneur's immediate (strong-tie) network; thus, because entrepreneurs interact with weak ties only occasionally, it is likely that weak ties will provide more unique information than strong ties. This notion is also in accordance with the findings of Burt (2004), to the effect that new ideas tend to emerge through weak ties between separate social clusters.

Altogether, it seems reasonable to assume that these three viewpoints, related to the networking behavior of firms, constitute an appropriate approach for theorizing on how internationalizing SMEs behave amid the pressures of institutional distance and multiple logics.

\section{Methodology}

The context: the institutional distance between Nordic countries and France 
France is culturally different from Nordic and English-speaking countries in many respects (Hofstede 2001; Ronen and Shenkar 1985; Trompenaars and Hampden-Turner 1997). It can therefore be anticipated that institutional distance may become a significant factor when Nordic SMEs seek to internationalize in French markets. As argued by Trompenaars and HampdenTurner (1997), French culture (along with other Catholic cultures) belongs to the set of caseoriented cultures. Viewed in this light, laws (in the legal sense) may not be seen as applying absolutely, and infringements of laws are not necessarily condemned. By contrast, in countries with universal cultures (such as Nordic countries), there is one single truth, and people are expected to obey laws, regulations, and contracts.

Pursuing this argument (Trompenaars and Hampden-Turner 1997), the French can be considered collectivist: they are likely to take other people into consideration, and they tend to be strongly attached to their families. People in Nordic countries are much more individualistic in these matters. Another aspect to consider is power distance, defined by Mulder $(1977,90)$ as "the degree of inequality in power between a less powerful individual (I) and a more powerful other $(\mathrm{O})$, in which I and O belong to the same social system.' France has the highest rank of all the European countries in power distance (with a score of 68). Nordic countries have a considerably lower power distance score (giving Finland a score of 33) (Hofstede 2001).

According to Trompenaars and Hampden-Turner (1997) French firms can further be roughly be divided into families and "Eiffel towers,"' both of which are characterized by a strong hierarchy. Authority is held by the father in SMEs, and by the highest hierarchical level in larger firms with several hierarchical levels. In such a configuration, tasks are clearly assigned and differentiated, and the compartmentalizations may not be readily understood by people from Northern Europe (D’Iribarne 1998; Szymanski 2000). Furthermore, decisionmaking in French firms generally takes place at the highest level of the hierarchy. In this connection, it has been suggested that the French are relatively punctilious regarding titles, 
statuses, and protocols, and sensitive to the possibility of being underestimated by their partners (D’Iribarne 1998; Hill 1992).

A number of other differentiating tendencies have been proposed. In France, there is considerable tolerance of uncertainty (giving an "uncertainty-tolerance" score of 86). Hence, the French tend to focus on problems that are immediately pressing rather than develop longterm strategies (Hofstede 2001). By contrast, in the Nordic countries (Swedish score 29), uncertainty is avoided to a significantly greater extent (Hofstede 2001, 151), indicating a desire to plan strategies well in advance. France also represents a diffuse culture, in which a customer is not merely a customer as in the Nordic countries: for the French, a client also represents a relationship that may develop into a friendship (Trompenaars and Hampden-Turner 1997). In such a culture, launching and developing business relations takes time, since the French will want to learn to know the foreigner fairly well before moving on to business matters.

According to Lewis (1996), the French tend to adopt a polychronic time view. People are flexible and expect to do several things simultaneously, frequently without planning matters in advance. Past, present, and future co-exist, and punctuality is a relatively insignificant factor. The Nordic countries, by contrast, are considered to represent a monochronic time view, meaning that people do one thing at a time, according to a plan (Lewis 1996). Finally, as noted by Toivanen (2000), it is important to bear in mind that the French language is the core of French identity and culture.

\section{Research design and case selection}

With a view to theorizing on the international networking behavior of SMEs when entering an institutionally different market, we used an inductive, multiple-case research design, following Eisenhardt and Graebner (2007). Here, the potential of case research is seen to lie in its capacity to induce new theoretical insights from empirical data (Welch et al. 2011). This research design 
was also seen as appropriate in studying complex phenomena that cannot be separated from their context (cf. Bonoma 1985). The case study firms were selected according to the following criteria:

(i) Nationality/size/industry: The firms had to be Finnish and to employ fewer than 250 employees at the time of the interviews (OECD 2003); they also had to belong to the manufacturing industry. Here it should be noted that Finland is a small and open economy in which internationalization is almost a necessity, and that a significant majority of Finnish firms are SMEs. The manufacturing industry is typical of SMEs, and by selecting SMEs from a particular industry, we sought to minimize the effect of the industry in a cross-case comparison.

(ii) Degree of internationalization: The firm had to have at least $30 \%$ of its sales from abroad, either directly or indirectly.

(iii) Target market: The firm had to operate regularly in the French market.

(iv) Intermediaries or subsidiaries as operation mode: The firm had to have its own foreign intermediaries and/or partners, via whom products were delivered, or to own foreign subsidiaries, or to engage in a combination of these two. Hence, we excluded firms with only indirect exporting.

Table 1 summarizes the key information on the case firms.

*** Insert Table 1 about here $\mathrm{F}^{* * *}$

\section{Data collection}

The main form of data collection was interviewing. The interviews $(n=22)$ were conducted mainly with Finnish managers, but also with the French cooperators. We also collected secondary materials, such as web pages, annual reports, financial records, minutes of meetings, and brochures. The secondary material was used to understand the history and the products of 
each firm, to form detailed case histories, and to understand the circumstances behind certain events, with particular reference to international network partners. The secondary material was also utilized for triangulation with the information given by the informants (see Table 2 for further information on the data sources from each case firm).

***Add Table 2 about here ${ }^{* * * *}$

We interviewed those persons who had maximum in-depth knowledge concerning internationalization. Hence, we included executives (entrepreneurs), managing directors, managers of international affairs, and sales administrators among our interviewees. The four interviews that took place in France were conducted with all the potential French parties whom we were able to access; thus, the interviews were conducted on a face-to-face basis with the French subsidiary managers and agents. These interviews allowed us to gain a more versatile understanding of the internationalization process overall, and in particular, of the role played by institutional distance and by differences between French and Finnish institutional logics. The French informants helped us significantly in understanding the challenges experienced by the French in dealing with Finnish SMEs.

At the start of the interview, neutral and non-threatening questions were asked to establish a relationship of mutual trust (see Svendsen 2006). The interviewees were then asked to describe their business in general and thereafter their internationalization and their international networks in particular. All the questions were developed according to the guidelines issued by Yin (1994), with the aim of making the questions as non-leading as possible. Because the interviews focused on the entrepreneurs' past experiences, we followed the guidelines for retrospective studies issued by Miller et al. (1997), and by Huber and Power (1985). 
All the interviews were digitally recorded and transcribed verbatim using a word processor. During the second listening, correspondence between the recorded and the transcribed data was ensured. The complete case reports were sent back to the interviewees, and any inaccuracies they noticed were corrected on the basis of their comments. In addition, email communication was used to collect further information from the interviewees, and to clarify inconsistent issues, if necessary.

\section{Data analysis}

In our data analysis, we followed the guidelines of Miles and Huberman (1994), proceeding through the following phases: (i) data reduction, (ii) data displays, (iii) conclusiondrawing/verification. The phases proceeded as follows:

(i) In the phase of data reduction, the data were simplified by highlighting extracts concerned with the international networking of the firm, then labeling the data in an Excel program. More than 50 labels were formed in the first stage, but following reduction we ended up with 11 categories: initiating international NTs, experiences of institutional distance, strong ties, medium ties, weak ties, communication with international NTs, terminating international NTs, forming new international NTs, indicators of the structural holes mechanism, indicators of the network closure mechanism, and adjusting to the strategy of the agent/subsidiary. These categories were taken as analytical units (see below).

The categories above can be illustrated from the case of Epsilon. Here, the international networks were initiated in trade fairs, and through being physically present in the French market. Epsilon did not report any significant experiences of institutional distance, and the persons concerned met and communicated regularly with the NTs in France. As regards the analysis of strong ties and network closure, Epsilon had been able to develop strong ties with the main French collaborator (a joint venture partner), and medium ties with certain existing 
agents with whom the ties had originally been weaker. As regards weak ties, and the mechanism of structural holes, Epsilon had ended collaboration with those ties which did not reach the level of at least medium or fairly strong. The firm had also built some new, weak ties (i.e. in addition to the existing strong and medium network ties), thus indicating the presence of a structural holes mechanism in the later, and not merely the early stages of internationalization in the French market. Overall, in terms of adjusting to the strategy of the agent/subsidiary, Epsilon had been successful in allowing two institutional logics to co-exist, while nevertheless creating a cross-institutional consensus.

The example of Beta contrasts in important respects with that of Epsilon. Beta, too, had found its original French network ties in trade fairs. There had been experiences of institutional distance related to a pronounced hierarchy, the need for regular communication, and to the time view (with consequent delays). There had been long periods of irregular communication. The originally weak tie had developed into a medium tie, and it has remained on that level up to the present.

In Beta, network closure has been the focus throughout the firm's history, and the structural holes mechanism was present only initially, i.e. when Beta knew nobody in France, and when its personnel travelled to trade fairs. As regards adjusting to the strategy of the agent/subsidiary, Beta has not done that to any significant extent. In fact, it is still in the phase of "deepening NTs within situations of institutional distance" (see Phase 2 of the cross-case analysis, below).

We wrote a detailed case history of each firm. This procedure is in line with Pettigrew (1990), who suggests that organizing incoherent aspects in chronological order is an important step in understanding the causal links between events. The unique patterns of each case were subsequently identified, then categorized within the eleven analytical units derived from the research question. These analyses were combined with secondary data, with a view to 
analyzing the networking activities over time.

(ii) In the data display phase, the relevant data were collected in a table, with the case firms as rows and the eleven analytical units referred to above as columns. We also created figures and network charts to show the development of networks in the French market over time, some of which are presented in this paper (see Table 3 and Figure 1). At this stage, we also conducted cross-case analyses, depicting both similarities and differences in the international networking of our SMEs. An example of this would be from Beta and Epsilon, as described above. These showed a similarity in finding their initial network ties at trade fairs, but differences regarding the presence of institutional distance, frequency of communication with the French parties, and the presence of strong, weak, and medium ties. There were further differences relating to the roles of structural holes and network closure mechanisms, and the ability to adjust to the strategy of the agency/subsidiary.

(iii) In the conclusion/verification phase, we concentrated on finding aspects that appeared to be significant. We noted regularities, patterns, explanations, and causalities in the international networking behavior of the SMEs, and became aware of issues related to networking and its relation to experiences of institutional distance. Once we had developed preliminary analyses from the retrospective data, we combined the analyses and induced a framework, using methods for building theory from case studies (Eisenhardt 1989). We selected pairs or groups of firms, listing similarities and differences between each pair/group, and categorized the firms according to variables of interest. These included the first NTs enabling internationalization, the deepening of relationships in a situation of multiple institutional logics, and achieving a stronger cross-institutional consensus. We then revisited each case to see if the data confirmed the relationship initially conceived. Here, the case examples Beta and Epsilon (see above) are illustrative in showing major difference in these aspects. Thus, Beta experienced major challenges related to the differing institutional logics in 
question, while Epsilon did not have this problem. It can be concluded that Beta is still in the phase of deepening relationships in a situation of multiple institutional logics, whereas Epsilon has been able to achieve a strong cross-institutional consensus.

After several iterations between the data and the framework, we used existing literature to sharpen the insights from the inductive analysis. In a similar manner to Eisenhardt (1989), the framework was found to fit the evidence, but not to explain the cases perfectly. An imperfect fit can be seen, for example, in the fact that those case firms which gave entrepreneurial freedom to their French collaborators, and which avoided pressurizing the other party into a particular logic, were able to find a way through the relevant institutional complexities. By this means (as discussed in more detail below), they achieved a basis for a cross-institutional consensus, involving a joint business culture.

\section{Findings}

Table 3 below summarizes the main analytical findings of the current study. We examined the interrelations between institutional distance and international networking within an institutionally different market, applying the following perspectives: (i) a structural holes (SH) perspective; (ii) a network closure (NC) perspective; (iii) the strength of the NTs; (iv) experiences of multiple institutional logics.

In the analysis of the data, the relationship was categorized as follows:

(i) strong if the relationship with the foreign co-operator(s) was close, based on trust, mutual respect, open communication, commitment, similar values, a passion for the field, and freedom to act according to one's own personality and creativity;

(ii) medium if there were only two or three of the following features in the relationship with the foreign co-operator(s): closeness, trust, mutual respect, open communication, commitment, freedom to act according to one's own personality and creativity; 
(iii) weak if the relationship with the foreign co-operator(s) had most of the following features: distance, a lack of trust, a lack of mutual respect, a lack of open communication, a lack of freedom, and a lack of commitment.

Alpha entered the French market via its French importer, who suggested to Alpha that its product (one component of which the importer was producing) could sell in France. Initially, the importer became an exporter for the firm. However, after a year, Alpha, together with the importer, found a suitable agent to represent Alpha. Alpha's relationship with the importer has remained at a medium level throughout the history of the firm. Alpha has continued cooperation with the same agent since 1991. It regards the relationship of the firms as good, although it would wish to have more sales in France. The NC activity of Alpha can be regarded as medium, since the interaction with the French agent is based on emails and phone calls, and rarely on more extensive social interaction. As Table 3 shows, Alpha has experienced some institutional distance related to differences in the view of time and habits of communication in France; nevertheless, it has been relatively easy for them to deal with these aspects, thanks to the importer tie.

***** Insert Table 3 about here. ***

Beta attended trade fairs in France after the mid-1960s. A suitable agent who "felt like a good, trustworthy guy" was found in 1968. No French NTs have been added since then. NC has been a primary activity of Beta since the initial entry, but the intensity of the interaction has been medium; the firms communicate mainly via emails and phone calls. Initially Beta visited the exporter personally twice a year, but currently they meet once a year in trade fairs in Europe. Beta has experienced the effects of multiple institutional logics in relation to the high hierarchical distance in France; also regarding the need of the French for more social and 
regular communication, and the different time view of the French, which has led to delays. The strength of the tie with the French agent is still medium, even after forty years of exporting, but this might be partly connected to the mode of operation, which is export via agents.

Gamma found two agents via Finpro, an export promoting organization operating also in France. One of them was a woman of Finnish origin who had been living in France for a long time. She established a sales subsidiary for Gamma. The other was a Belgian man, who started as their agent. Simultaneously with launching the sales subsidiary and starting with the agent, Gamma looked for and sent a Finnish entrepreneur (known previously to the company) to France for one year, to demonstrate the good qualities of its forest machinery. Due to strategic changes in Gamma, the forest machine sales were transferred to another company, and the subsidiary closed down. Only the Belgian agent was still operating at the time of the interviews. Gamma also emphasized the need for social interaction in order to deepen the relationship. This is needed simply to start to talk about business - at which point the NT can move to being social. The international sales manager of Gamma expressed the matter as follows:

It's about small talk. You go to your partner's home for a dinner in the evening and you don't say a word about business. First of all you create your relationships and show what you're like in every situation: when there are problems, when good things come your way, how you behave when you're celebrating, how alcohol changes you, that's what they want to see. And when they've seen you on different occasions, it will help a lot, and things will go on from there [...] Once you've sold the machine, you also become a family friend. They call you about things other than just business matters, they come to your home, they ask you to their home, and they are extremely friendly. It's about friendship alongside business. It really takes time to have the trust of the French, and there can be many kinds of problems and misbehavior in the meantime. [...] But once 
they trust you, they are extremely friendly and they become friends that you also meet in your free time.

Gamma experienced institutional distance in relation to legal issues when it set up the sales subsidiary. It recommends hiring a lawyer for the French market.

They had totally different laws for setting up a firm, for hiring labor, taxation. When you enter a new market, you need to find a lawyer who will be a source of security for you. If there are misunderstandings, he can tell you what to do. However good a friend you may be with your co-operator, once you come up against a disagreement, the friendship won't help anymore.

Delta attended trade fairs in the 1990s to find suitable NTs for the French market. Originally, Delta found two suitable agents. Since the beginning of the 1990s, seven new agents have been added at regular intervals to the circle of agents (currently standing at seven), via trade fairs and unsolicited agreements. However, two agent agreements have also been terminated, at the initiative of the agents. Delta has had a strong focus on building NC with their agents, being in daily contact with them. The company has experienced the effects of multiple institutional logics in relation to the need of the French to communicate often, even without any real reason; this contrasts with the Finns, who are accustomed to communicating only when something needs to be solved:

Many entrepreneurs make the mistake of hiring an agent and then calling him up a year later and wondering why the sales haven't got off to a good start. We learned that we need to be active ourselves. French people are really keen on service. 
The international co-operators of some of the other case firms indicated a sense of having been left alone. The case firms, however, thought they had shown trust by not communicating with the foreign NTs so often - a belief which proved to be misguided.

Epsilon is a further example of a firm which found the original NT for the French market by attending trade fairs in France. Epsilon is still adding new NTs to its circle of agents, currently three in different geographical regions of France. It has also terminated two problematic agencies in different parts of France: the CEO felt the NTs were not good enough, and that the sales levels had remained too low for too long. Epsilon had invested strongly in building strong NC with its French agents during earlier phases: the current CEO lived for a couple of years in France at the start of the 1990s, seeking to strengthen the NTs via more intense interaction (dinners and other face-to-face meetings), and to build opportunities for more extensive business there (i.e. going beyond exports). In addition to the three agents, Epsilon actually has a production joint venture in France. It looked for suitable production opportunities in France through two intermediary organizations, Invest in France and Finpro. A suitable partner was found through Invest in France, and a joint venture involving a production plant was established in 2006. The CEO of Epsilon regards institutional differences as almost insignificant, and has not experienced the effects of multiple institutional logics. It seems that when one is entering a foreign market, extensive experience abroad diminishes the sense of institutional distance. Epsilon has thus taken a vigorous approach to networking:

I see networking and strategy renewal as constant. We can never see what is happening, we need to act ahead of all of that. We made a very good choice that we did not establish a joint venture with one of our good distributors, and instead waited for, and eventually found, an excellent French partner via Invest in France. 
Zeta entered France after finding a suitable agent in trade fairs, one that seemed to be a very good fit for its business. After some good sales for a couple of years, a subsidiary financed by Zeta was established, and the agent became the CEO of the agency, on the basis of confidence and trust in the agent:

We ended up setting up a subsidiary after two or three years of exporting, because they were doing so well and we wanted them to concentrate only on our products. The manager of this subsidiary was a very good type of person and we had confidence that it was worth investing money in this firm.

However, the cooperation with the French subsidiary managers has been problematic for Zeta, since it was forced to change the subsidiary manager three times (at approximately two-year intervals) in the 1980s and 1990s. On each occasion the reason was the misbehavior and/or a low level of activity on the part of the subsidiary manager. From the point of view of headquarters, the weak level of the relationship could be related to too high a level of control, and to irregular communication with the subsidiary:

Now, since then, I've also understood that we left them too much on their own. We also had some misbehavior on their part, because they realized that we weren't checking them. It's so important for the French to have a feeling of togetherness, but what we had with them was too much 'us here' and 'you there'.

The current CEO of the Zeta French subsidiary explained the institutional distance that they had encountered with the Finns, concluding that the final outcome had been a hybrid FrenchFinnish business culture:

I would say that the Finnish management has a vision that is too Finnish-oriented. And here we are of course in France and we have a different vision of the market. Our clients 
need good service and somewhat differentiated products, but the management at headquarters wants to keep to the Finnish standards, and that is a great mistake. When, for example, we explain that we should get a lighter range, they do not consider this. They listen to what you say, it is an open discussion, but it does not mean that anything happens... Altogether I think this is the middle way - we are not doing things in a French way, but we have merged many features of Finnish business culture in relation to our operational logics. Somehow I cannot even remember anymore how a pure French business culture is, since we've been working together such a long time.

Eta was able to enter the French market on the basis of a strong, existing NT:

We were good friends. It was very natural that we would start to cooperate after I launched my new firm. Well, it happened spontaneously, because we were such good friends. I don't even know who asked first, me or him. He wanted to work for me and not for my previous firms, which had been taken over, so he resigned right away when he heard about my new firm. [...] Over all these years, I have got to know him extremely well. We can trust each other 100\%, we have respect for each other's opinions, have similar kinds of values in life, and are interested in similar kinds of things. [...] We do not communicate that often, but we can always proceed from where we left off last time. He does not think about money so much, all the other aspects come first. And he also gives me freedom. I feel so comfortable with being able to run the French subsidiary my way. We have created an approach of our own during all these years of cooperation.

The extract above also describes a strong NT with $100 \%$ trust, respect, and similar values, with the social side of the relationship coming first, plus entrepreneurial freedom given to the subsidiary manager. 
The CEO of Zeta has had a strong tie with the French subsidiary manager over a period of thirty years. Thanks to him, the CEO has not needed to think too much about institutional distance. The primary factor has been the personal relationship, indicating that the presence of an existing strong tie in a foreign market makes the internationalization process very different, diminishing the institutional distance perceived by the case firm.

Theta entered France in 1998. The aim was to export, based on a chance encounter with a French agent who offered to sell the log houses of Theta in France, and who believed in the potential of the product.

We had no plan to go to France. My colleague just met this French guy by accident. He said that he wanted to sell our log houses in France. [...] Well, then I went to see him and said okay, just go ahead and start selling our log houses. [...] We (the informant and the French guy) started by searching for local partners. They told us about the needs of the customers, we made the offers and they passed them on to the customers. We played with these potential partners for many years, but none of them turned out to be trustworthy or able to sell. They just took our time and money. On one of the trips we went to Paris and met a man who ordered thirty log houses. And none of them were actually delivered. He just cheated us.

In the initial phase, Theta quickly reacted to the unsolicited offer and built up an extremely trustworthy relationship with the agent, with cultural differences also taken into account. However, Theta was very unsuccessful in building its retailer network, since none of the persons taken on as potential partners was successful to any extent. Moreover, it had not done anything to advance networking in the French market after this initial attempt, deciding in the end to establish a representative office. 


\section{Cross-case Analysis and Discussion: Development of International Networking among Nordic SMEs Operating in France}

On entering an institutionally distant market, the networking of the case SMEs seemed to have the following characteristics, with certain phases tending follow each other. Prior to entering the institutionally different market, the network of the SMEs (in relation to the target market, France) was based on an importer tie (Alpha), a strong existing NT (Eta), or no existing NTs (six case firms). The actual phases in the internationalization process were the following:

(i) Two case firms (Alpha and Eta), who had existing NTs in the French market were able to use them for the foreign market entry (FME); however, the remaining six case firms looked for French (and other international) NTs in trade fairs (Beta, Delta, Epsilon), or via an exportpromoting organization Finpro (Gamma, Zeta), or else reacted to unsolicited orders from interested French parties (Theta). Most of the case SMEs selected parties that appeared to constitute medium-level ties, paying attention to signs of trust and commitment in them. This can be called the phase of recognizing and selecting NTs and entering the market. It is mostly related to the $\mathrm{SH}$ mechanism and in terms of strength, it is related also to the weakness of NTs among case firms with no prior NTs in the French market.

(ii) Next, the SMEs started to deepen the selected NTs. We found this phase to be strongly driven by the partners' cognitive and normative prescriptions (i.e. institutional logics) concerning appropriate behaviors in relationships. The problematic issues related particularly to communication, hierarchy, the view of time, and legal complexity. In fact, six out of eight firms are still in this phase, i.e. dealing with the demands of institutional distance. This indicates unwillingness or difficulty as regards deepening the medium/weak NTs into strong NTs. We noted that it was especially important to terminate the selected network relationship, if it did not show signs of trust and commitment. 
(iii) Epsilon and Eta became more deeply embedded with their French NTs than the six SMEs that were still trying to deepen the French NTs (on the basis of trying to get the French to adjust to their institutional logic). The CEOs of Epsilon and Eta understood that the institutional distance was significant, and that it might not be wise to make active efforts to merge their different logics of action in this phase: thus they gave entrepreneurial freedom to the agents, the staff in the subsidiary, and the joint venture partners. This meant that the French collaborators had the possibility to work on the basis of their own logic, and were not forced to conform to Finnish logic. Here we can see a phase of allowing two institutional logics to coexist, which is related to strong network closure and strong ties. The ability to do this might be related to the extensive experience of the Epsilon CEO, who had lived in France and the longterm relationship of the Eta CEO with the subsidiary manager.

(iv) The deepest level in dealing with institutional distance involved a strong crossinstitutional consensus and further NTs. After the two institutional logics had co-existed, the CEOs of Epsilon and Eta could be regarded as having shaped a joint business culture and strategy with the French subsidiary/joint venture, in which the features of the French and Finnish cultures were at last partly merged. This was related to an NC mechanism and to strong ties, but also to an $S H$ mechanism, since Epsilon, thanks to its strong ties, was able to build further NTs in the French market for its future needs.

In relation to the above, Figure 1 illustrates the relationship between institutional logics and international networking when Nordic (Finnish) SMEs do business in France, i.e. when two institutionally different contexts co-exist. It illustrates the interaction between networking and institutional distance interaction, plus the phases in it, from (i) to (iv), undertaken by the case companies, when they entered and operated in the French market during their 10-40 years of international operations. Six out of the eight case companies were still at Phase (ii). Thus, they were struggling with challenges connected to wishing that the French would operate 
according to Finnish institutional logics. In contrast, two companies (Epsilon and Eta) had entered Phase (iv), involving a cross-institutional consensus.

****Insert Figure 1 about here $* * *$

\section{Phase 1: Recognizing and selecting NTs, and entering the market}

The first step in the internationalization of the SMEs was the finding of suitable NTs for their internationalization. Institutional distance did not play any significant role in this phase. This phase was based on (i) strong ties, when earlier ties in the French market had enabled the entry, and when the network closure with them had strengthened sufficiently to advance operations in the market; (ii) weak to medium ties, when new NTs needed to be sought for entry into the market (via the bridging of structural holes). Alpha was able to use its existing French importer tie to launch exports in France. Gamma used a Finnish entrepreneur, already known to the firm, as another means of fostering sales in the French market. Eta was the third case firm that was able to use an existing NT for the French entry. However, Eta was exceptional among all the eight case firms (including in comparison with Alpha), since it was the only company, which had truly strong existing NTs. This was what allowed it to establish a subsidiary in France in the first place.

Among the remaining five case firms, suitable ties were found by attending international exhibitions, by contacting Finpro (a Finnish export-promoting organization), or by reacting to unsolicited approaches offered by unknown customers/agencies. Here the lack of existing international NTs was a predominating factor. Nonetheless, the case firms did not find suitable NTs at all the exhibitions they attended: they were, in fact, fairly fastidious about the network personnel they wanted to cooperate with. They only started cooperation with people who "felt 
good" or who "were suitable" for some other reason; more generally, they internationalized only into foreign markets where they found reliable cooperators.

In relation to unsolicited approaches, the case companies were ready and willing to follow them up, since they involved very little risk, if any, and there was no harm in giving them a try. Nevertheless, here also the quality of the person mattered. Our findings are in line with Coviello (2006), indicating that even among more traditional SMEs (as opposed to hightechnology INVs), the NTs that existed abroad prior to internationalization were important. However, among our case firms, these seemed to be more often social than business ties.

An important feature in Phase (i) was the selection of NTs which quickly grew to medium strength. When the case firms developed these newly-found NTs into medium-level ties, the decision to enter France became self-evident, because of the adequate level of trust between the cooperating parties. Some emails were exchanged, and some knowledge of the person was gained. Then, if there was still a positive "gut feeling," the decision was taken rapidly, without any need for extensive strategic deliberations. To put it simply, in entering a foreign market, a medium level of trust was needed, but institutional distance was not likely to be a major issue.

\section{Phase 2: The deepening of NTs within situations of institutional distance}

Once the case firms had found a suitable network, a phase followed of either deepening or terminating NTs within a situation of institutional distance. This was related to the NC mechanism, whose operations include a desire to move towards strong/stronger ties. Eta was able to skip this phase because of the owner-manager's strong existing NTs, but the remaining seven case firms, who had initial medium-level NTs, expended considerable resources on, first of all, deepening the NTs (despite the differences that they faced regarding institutional logics). In the case of Epsilon, Gamma, and Zeta, there was also termination of problematic NTs. The aim here was for the companies to avoid spending too many resources on developing 
relationships which did not show signs of bearing fruit. However, our data suggest that there could be many traditional SMEs that will tend to stick with the same collaborators, even in cases where cooperation is not necessarily very successful (with the failure being due to an inability to deal with institutional distance, or else to more personal matters).

The deepening of the NTs required considerable adjustments from the case firms, related to the French collaborators' need for regular communication and strong social interaction. In addition, adjustment involved getting used to the collaborators' attitude to hierarchy, their view of honesty, their time view, their daily rhythm, and legal differences. As our case evidence indicates, this is a crucial phase, and one that is hard to progress beyond if the cognitive and normative prescriptions of institutional logics in the French market are not fully understood and taken into consideration. In fact, six out of the eight case companies (Alpha, Beta, Gamma, Delta, Zeta, and Theta) were still in the middle of this phase at the time of the study, i.e. they were in the process of trying to deepen the NTs. However, since they tried to act in France in the Finnish way (with some incremental adjustments), they were unable to advance further. In other words, it can be argued that these six SMEs still did not understand that there is a notable distance between Finnish and French ways, in terms of making sense of the surroundings, and the appropriate activities and responses in social situations; also that behavioral tendencies driven by institutional logics cannot easily be reconciled.

It is interesting that Eta, the only firm that internationalized instantly after its establishment, and Epsilon, which internationalized intensely after a generational change and after the son's entry on the scene, did not recognize the existence of institutional distance to such an extent, if at all. From their earlier experiences abroad, it appeared that the entrepreneurs in these firms had gained sufficient understanding of cultural differences, and that they did not need to struggle with them at this point. For Alpha, Beta, Gamma, Delta, Zeta, and Theta, by contrast, it came as something of a surprise that they had to act so differently in the French 
market if they were to make their businesses operate effectively. This meant that they expended considerable resources on dealing with the institutional distance related to interaction, communication, the way of working, hierarchies, and adherence to schedules.

The institutional distance experienced by the SMEs was very much in line with that identified in previous research (D'Iribarne 1998; Hofstede 2001; Trompenaars and HampdenTurner 1997). The matters of greatest concern for the SMEs in our dataset related to collectivism, i.e. the need for regular communication and social interaction (Trompenaars and Hampden-Turner 1997), hierarchy (D’Iribarne 1998), case orientation (laws not adhered to), uncertainty avoidance (schedules not adhered to, see Hofstede 2001), and diffuseness bound up with the need to see the customer as not just a customer but also as a family friend (Trompenaars and Hampden-Turner 1997).

Our findings are in line with Yli-Renko, Autio and Tontti (2002), since they indicate that, in particular, personal-level ties are of extreme importance in knowledge transfer from foreign markets. Our case SMEs developed their initially weak business ties into stronger ties via a strong personal element. However, in contrast to the findings of Yli-Renko, Autio and Tontti (2002), our SMEs were not able to use internal social capital for internationalization, needing rather to rely on external ties solely.

Overall, it seemed that most of the case firms had collaborated with the original NTs, to the extent that the firms might be over-embedded with their collaborators, leading to conformist and outdated patterns of thinking, and to a decline in competitive advantage. In other words, they were firmly located within the NC mechanism (Coleman 1988), but were largely unable to build the trust up to the highest levels. As a result, the relationship remained at a weak or medium level, due to institutional distance and resource constraints. Hence, due to an inability to deal with issues related to institutional distance, the SMEs were likely to get stuck in weakto-medium ties, and in the mechanism of network closure. 


\section{Phase 3: Allowing two institutional logics to coexist}

Epsilon and Eta became more deeply embedded with their French NTs than did the other six SMEs. The CEOs of Epsilon and Eta understood that the two institutional logics could not be imposed on each other, and they thus gave entrepreneurial freedom to the agents, the staff in the subsidiary, and their joint venture partners. This meant that the subsidiary staff was given the freedom to form a strategy of their own in relation to sales tactics, pricing, customer service, etc., and they were not forced to ask headquarters about every detail. The controlling management style practiced by the more traditional SMEs (see e.g. Gallo and Pont 1996; Graves and Thomas 2006) did not seem to suit the French partners, who wished to influence the strategy of the firm, and to have more possibilities for differentiation. In other words, these two SMEs understood that they could not "sell" their institutional logic, and would do better to let their target market partners maintain their practices. This allowed the French collaborators to work on the basis of their logic, without being obliged to adapt to the Finnish logic.

The inability of the more traditional SMEs to distribute decision-making power and to give entrepreneurial freedom was based on their own centralized decision-making, their strong internal enterprise culture (Gallo and Sveen 1991), and their habit of duplicating their domestic enterprise culture in the target market (Tsang 2002). By contrast, Epsilon and Eta were able to overcome institutional distance by letting two institutional logics live separately and simultaneously. Hence, it seemed that giving entrepreneurial freedom to foreign collaborators, i.e. allowing two institutional logics co-exist, helped in building strong NTs abroad within situations of institutional distance.

Phase 4: A deep cross-institutional consensus, and further NTs 
After allowing two institutional logics to co-exist, Epsilon and Eta went further and created $a$ Finnish-French business culture together with their French collaborators. This can be referred to as a cross-institutional consensus. Such an approach was possible on the basis of a very good level of trust and NC between the headquarters and the subsidiary/joint venture managers/agents of the companies in question. The subsidiary manager of Eta expressed the matter thus: "I think this is a middle way - we are not doing things in a French way, and instead have merged many features of Finnish business culture with our operational logics.”

This sort of consensus also enabled the SMEs to bridge structural holes, creating new network ties for future needs. Epsilon, as distinct from all the other seven case firms, built new NTs for future needs, considering possibilities for future expansion. After Epsilon had built good relationships with its original cooperators, it further networked actively on many different occasions, met customers personally, contacted intermediary organizations, and sought potential cooperators through registers. In other words, Epsilon was able to look for and develop NTs other than the network with their primary cooperator. This gave the firm opportunities for growth in the market and for differentiating strategies in different parts of the country.

Epsilon was the most successful of all the case companies in terms of its international sales and profits. Putting it differently, one could say that Epsilon had actively tried to bridge SHs (Burt 1992) in the foreign markets. This type of network strategy was launched after the company was successfully passed to the son of the founder of the company. These new NTs enabled Epsilon to find agents to replace poor ones. The cooperation with intermediary organizations such as Finpro and Invest in France helped them to find a joint venture partner, and this made it possible to launch a production plant in the French market.

\section{Discussion and Conclusions}


Returning to our original research question, concerning the adaptation of SMEs to differences in institutional logics, we found that institutional distance was strongly related to sub-optimal international networking in the majority of our case firms. Our findings demonstrate how international networking activities are influenced by institutionally prescribed logics of behavior, possibly leading to conflicts or misinterpretations in a foreign context, even when that context is geographically / physically close. These observation provide important advancement on understanding how and why institutional distance matters (cf. Kostova and Zaheer 1999; Xu and Shenkar 2002; Salomon and Wu 2012) at the level of operational activities of internationalizing firms. By showing how firms attempt to solve the challenge of institutional distance in their networking activities, we specifically shed new light on internationalization and network ties as they progress over time (see e.g. Ellis 2000; Jack 2005; Prashantham and Dhanaraj 2010; Yli-Renko, Autio, and Tontti 2002), contribute to the literature on the development of entrepreneurial network ties (Anderson and Jack 2002; Gedajlovic et al. 2013; Hoang and Antoncic 2003; Jack and Anderson 2002; Jack, Dodd, and Anderson 2008; Johannisson 2000; McKeever, Anderson, and Jack 2014), and importantly, add to the research focusing on the actor-level implications of institutional logics (Dalpiaz et al. 2016; Pache and Santos 2013; Thornton et al. 2012).

We also respond to the call of Delios (2017), who identified a need for more contextspecific research within the regions in which companies are engaged (Delios, 2017). In the present case, this need is addressed through in-depth insights from SMEs collaborating in two culturally and institutionally distant countries, namely Finland and France. We observed that two case SMEs were able to understand and overcome different institutional logics, and later to allow them to co-exist, thus creating a cross-institutional consensus. Over time, these two firms were able to do more with networks than the six SMEs which experienced significant behavioral tensions, and which were therefore unable to develop strong ties or more numerous 
weak ties in the institutionally distant market. In addition to having the capabilities to build strong ties (which cannot be built without appreciating the other party's institutional logic) via concentration on network closure, the two consensus-oriented SMEs were able to build new NTs via the mechanism of structural holes.

Specifically, our observations have a bearing on previous SME internationalization research, in terms of our findings regarding network ties and social capital. We found that the SME network developed from weak to strong ties, and that it did not grow very much in extent. This finding runs counter to that of Coviello (2006), who studied knowledge-intense SMEs. Thus, we add to the observations of Coviello (2006) in our finding that the range of NTs grew in the case of some SMEs; however, among most of our case SMEs the range grew slowly if at all.

Unlike the firms studied by Yli-Renko et al. (2002), our SMEs were not able to use social capital derived from family members or friends for their French business operations. In line with Prashantham and Dhanaraj (2010), the networks of the SMEs declined when the subsidiary manager was untrustworthy, the sales levels of an agent were not satisfactory, or the market needed to be closed totally. Despite this, there was a strong element of stability within the firms as well, considering the long time frame (from 30 to 50 years). Several of the case firms showed very few changes in the range of NTs over the time frame. Interestingly, many of the changes that did occur were related to institutional distance, but sometimes also to poor sales and strategic changes.

The behavior of the majority of our case firms contrasts with the findings of Burt (1992, 2000), who emphasized the importance of weak ties. The case firms had only a few weak ties in the French market - even in a situation that would have allowed a large number of weak ties, due to low maintenance costs (Granovetter 1973; Singh 2000). The weak ties of the case firms were very quickly developed into medium ties, and to strong ties if possible. Alternatively, the 
ties ended, if they remained weak, or if they became weak at a later date. This finding is in line with Chetty and Wilson (2003); thus, Epsilon (who networked with a competitor and formed a joint venture) was the most internationally involved and the most rapidly growing of the case SMEs. Altogether, the network behavior observed seemed to be a reflection of mastering - or else not mastering - institutional distance.

In line with Prashantham and Dhanaraj (2010), we discovered that the SMEs might have been over-embedded with their collaborators, in that they concentrated on NC, rather than on the SH mechanism. After the initial stage, the SH mechanism was used to a limited extent, most extensively by Epsilon, but to some extent by Delta, who added new agents at roughly two-year intervals. The SH mechanism was not used at all by the six remaining SMEs. Hence, in an institutionally distant market, SMEs preferred to concentrate on NC rather than $S H$. This seems to be related to the inability of the SMEs to deal with institutional distance, which at the same time, prevents them from building further network ties. Indeed, it seems that the psychic distance paradox was valid when the Finnish firms operated in France (see O'Grady and Lane, 1996); thus, although France is geographically fairly close to Finland, and although both countries belong to the European Union, the firms had difficulties in grasping the significant role of psychic and institutional distance.

Our findings corroborate the findings of Gargiulo and Benassi (2000) concerning the difficulty of simultaneously maximizing the two opposing mechanisms, SH and NC. We show how this would nevertheless have been necessary for the optimal internationalization of the SMEs in question. It was clear that further growth would have required both a good level of trust and further network ties (something that was achieved only by Epsilon and Eta). This was specifically related to an inability to master the factors of institutional distance.

Interestingly, our findings revealed that the foreign market entry became possible purely on the basis of a degree of trust and some gut feeling. However, institutional distance began to 
play a significant role immediately after FM entry. Six out of the eight SMEs were unable to deal with the multiple institutional logics in question (related to hierarchy, communication, the time view, legal differences, and the level of social interaction), or at least not with all aspects of these. The result was that, for as long as the SMEs were unable to change their interpretation, and for as long as they tried to act according to their own practices, assumptions, and values, they became stuck within a situation of institutional distance, and hence locked within an unresolved NC mechanism, with concomitant weak to medium ties.

Nevertheless, two SMEs were able to proceed through the complexity. The first step to in tackling the tensions arising from competing logics was to give a medium level of entrepreneurial freedom to the French collaborators, and to avoid pressurizing the other party into a particular logic. Basically, the successful firms understood the need to act on the basis of two different (Finnish and French) logics. This enabled the SMEs to have good NC, encompassing strong ties. From this starting point it became possible to create still stronger NC, based on a cross-institutional consensus with the French collaborators, involving a joint business culture. This sort of consensus also enabled the SMEs to bridge structural holes with a view to creating new network ties for future needs. Cases such as this would suggest that effective network behavior may depend largely on a mastery of different institutional logics.

This study also points to aspects requiring further research. Our research was limited to firms entering a particular market, and we have only two examples of optimally successful networking. It is also true that having only two interviews (from some of the firms) could be seen as a limitation. However, taking into account the small size of the firms and the roles of the persons interviewed, it can be argued that these informants had the kind of crucial knowledge required for the purposes of our study.

From a managerial point of view, entrepreneurs would seem well-advised to attend international trade shows in order to find foreign NTs. To avoid spending a lot of resources on 
overcoming institutional distance, the managers would be further recommended to learn about the cultural features of the target market. The entrepreneurs should bear in mind that once they pursue the international route, they ought to be able to form an international attitude and give entrepreneurial freedom to their agents and subsidiary managers; by so doing it is more likely that their product will be differentiated according to the needs of the market in question. We would also recommend that SMEs could consider networking with co-operators with extensive networks, as suggested by Ahuja (2009).

Concerning policy implications, it seems to be important to set up multicultural forums for SMEs, so that they may better understand differences in institutional logics and be better prepared for setting up suitable NTs (see also McNaughton and Pellegrino 2015). There would also be a need for national programs to increase knowledge on internationalization, and on its influences on firms. Such programs could facilitate the internationalization processes of SMEs, who tend to be limited in their resources for market research, and for hiring staff with suitable cultural knowledge. Nations should further pursue intercultural education on different educational levels, and should encourage multicultural settings in their study programs, thus providing interculturally aware individuals for working life. On the other hand, all individuals should be reminded of the importance of institutional logics and cultural differences: although the world is becoming smaller, cultures and institutional environments remain very different. Thus, knowledge and an open mind are required if one is to deal with them successfully.

\section{References}

Agndal, H., and S. Chetty. 2007. "The Impact of Relationships on Changes in Internationalisation Strategies of SMEs.” European Journal of Marketing 41(11/12): $1449-1474$. 
Ahuja, G. 2000. "The duality of collaboration: inducements and opportunities in the formation of interfirm linkages.” Strategic Management Journal 21: 317-343.

Anderson, A. R., and Jack, S. L. 2002. "The articulation of social capital in entrepreneurial networks: a glue or a lubricant?" Entrepreneurship and Regional Development 14(3): 193210.

Berry, H., Guille'n, M. F., and Zhou, Z. 2010. “An institutional approach to cross-national distance.” Journal of International Business Studies 41(9): 1460-1480.

Bonoma, T.V. 1985. "Case Research in Marketing: Opportunities, Problems, and a Process." Journal of Marketing Research 22(2): 199-208.

Burt, R.S. 2010. Neighbor Networks: Competitive Advantage Local and Personal. Oxford University Press, New York, NY.

Burt, R.S. 2004. "Structural Holes and Good Ideas.” American Journal of Sociology 110(2): 349-399.

Burt, R.S. 2000. "The Network Structure of Social Capital." Research in Organizational Behaviour 22: 345-432.

Burt, R.S. 1992. Structural Holes. Cambridge, MA: Harvard University Press.

Chetty, S. K., and Wilson, H. I. 2003. "Collaborating with competitors to acquire resources.” International Business Review 12(1): 61-81.

Coleman, J.S. 1988. "Social Capital in the Creation of Human Capital." American Journal of Sociology 94: S95-S120.

Coviello, N.E. 2006. “The network dynamics of international new venture." Journal of International Business Studies, 37(5): 713-731.

Dalpiaz, E., Rindova, V., and Ravasi, D. 2016. "Combining Logics to Transform Organizational Agency Blending Industry and Art at Alessi." Administrative Science Quarterly 61(3): 347-392. 
Delios, A. (2017). The Death and Rebirth (?) of International Business Research. Journal of Management Studies 54(3): 391-397.

D’Iribarne, P. 1998. Cultures et mondialisation. Seuil: Paris.

Eisenhardt, K. M. 1989. "Building Theories from Case Study Research." Academy of Management Review 14 (4): 532-550.

Eisenhardt, K. M., and M. E. Graebner. 2007. "Theory Building from Cases: Opportunities and Challenges." Academy of Management Journal 50 (1): 25-32.

Ellis, P.D. 2000. "Social ties and foreign market entry." Journal of International Business Studies 31(3): 443-469.

Ellis, P. D. 2011. "Social Ties and International Entrepreneurship: Opportunities and Constraints Affecting Firm Internationalisation." Journal of International Business Studies 42 (1): 99-127.

Gallo, M.A., and Pont, C.G. 1996. "Important factors in family business internationalization." Family Business Review 9(1): 45-59.

Gallo, M.A., and Sveen, J. 1991. "Internationalizing the family business: Facilitating and restraining factors.” Family Business Review 4(2): 181-190.

Gargiulo, M., and Benassi, M. 2000. "Trapped in your own net? Network cohesion, structural holes, and the adaption of social capital.” Organizational Science 11(2): 183-96.

Gedajlovic, E., Honig, B., Moore, C. B., Payne, G. T., and Wright, M. 2013. "Social capital and entrepreneurship: A schema and research agenda." Entrepreneurship Theory and Practice 37(3): 455-478.

Granovetter, M.S. 1973. “The Strength of Weak Ties.” American Journal of Sociology, 76(6), $1360-1380$.

Graves, C., and Thomas, J. 2006. "Internationalization of Australian family businesses: A managerial capabilities perspective.” Family Business Review 19(3): 207-224. 
Greenwood, R., Raynard, M., Kodeih, F., Micelotta, E. R., and Lounsbury, M. 2011. "Institutional complexity and organizational responses." The Academy of Management Annals 5(1): 317-371.

Gulati, R., and Gargiulo, M. 1999. "Where do interorganizational networks come from?" American Journal of Sociology 104(5): 1439-1493.

Harris, S., and Wheeler, C. 2005. "Entrepreneurs' relationships for internationalization: functions, origins and strategies.” International Business Review 14(2): 187-207.

Hill, R. 1992. We Europeans. Europublications: Brussels.

Hoang, H. and Antoncic, B. 2003. "Network based research in entrepreneurship: a critical review." Journal of Business Venturing, 18 (2), 165-87.

Hofstede, G. 1994. "The business of international business is culture." International Business

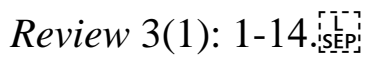

Hofstede, G. 2001. Culture's Consequences: Comparing Values, Behaviors, Institutions, and Organizations across Nations. Sage Publications: London.

Huber, G.P., and Power, D.J. 1985. "Retrospective Reports of Strategic-level Managers: Guidelines for Increasing their Accuracy.” Strategic Management Journal 6(2): 171-180.

Jack, S. L., and Anderson, A. R. 2002. "The effects of embeddedness on the entrepreneurial process.” Journal of business Venturing, 17(5), 467-487.

Jack, S., Dodd, S. D., and Anderson, A. R. 2008. "Change and the development of entrepreneurial networks over time: a processual perspective." Entrepreneurship and Regional Development, 20(2), 125-159.

Johannisson, B. 2000. "Networking and entrepreneurial growth". In Sexton, D.L. and Landström, H. (eds.) Handbook of entrepreneurship, 368-386. Oxford: Blackwell.

Johanson, J. M., and Mattson, Y. LG 1988. "Internationalization in Industrial Systems-A Network Approach.” Strategies in Global Competition. Croom Helm, London: 287-314. 
Johanson, J., and Vahlne, J.-E. 2009. "The Uppsala internationalization process model revisited: From liability of foreignness to liability of outsidership." Journal of International Business Studies 40(9): 1411-1431.

Johanson, J., and Vahlne, J. E. 1977. "The internationalization process of the firm-a model of knowledge development and increasing foreign market commitments." Journal of international business studies 8(1): 23-32.

Johanson, J., and Wiedersheim-Paul, F. 1975. "The internationalization of the firm: four Swedish cases." Journal of Management Studies 12(3): 305-322.

Kostova, T., and Zaheer, S. 1999. “Organizational legitimacy under conditions of complexity: the case of the multinational enterprise." Academy of Management Review 24(1): 64-81.

Lewis, R. 1996. When Cultures Collide: Managing Successfully across Cultures. Nicholas Brealey: London.išpep

McKeever, E., Anderson, A., and Jack, S. 2014. "Entrepreneurship and mutuality: social capital in processes and practices." Entrepreneurship and Regional Development 26(5-6): 453477.

McNaughton, R. B., and Pellegrino, J. 2015. Policy implications of international entrepreneurship. Routledge companion to international entrepreneurship: 235-244.

Miles, M.B., and Huberman, A.M. 1994. Qualitative Data Analysis: An Expanded Sourcebook. California: Sage Publications.

Miller, C.C., Cardinal L.B., and Glick, W.H. 1997. "Retrospective reports in organizational research: A reexamination of recent evidence." Academy of Management Journal 40(1): 189-204.

Mulder, M. 1977. The Daily Power Game. Martinus Nijhoff: Leiden.

OECD 2003. Officially-supported export credits and small exporters, Organization for Economic Co-operation and Development, France. 
Oviatt, B.M., and McDougall, P.P. 2005. "Defining international entrepreneurship and modeling the speed of internationalization.” Entrepreneurship Theory and Practice 29(5): $537-553$.

O'Grady, S., and Lane, H. W. 1996. “The psychic distance paradox.” Journal of International Business Studies 27(2): 309-333.

Pache, A. C., and Santos, F. 2013. "Inside the hybrid organization: Selective coupling as a response to competing institutional logics.” Academy of Management Journal 56(4): 9721001.

Pettigrew, A.M. 1990. "Longitudinal field research on change: Theory and Practice." Organization Science 1(3): 267-292.

Podolny, J.M., and Baron, J.N. 1997. "Resources and relationships: social networks and mobility in the workplace." American Sociological Review 62(5): 673-93.

Prashantham, S., and Dhanaraj, C. 2010. "The dynamic influence of social capital on the international growth of new ventures.” Journal of Management Studies 47(6): 967-994.

Ronen, S. and Shenkar, O. 1985. "Clustering countries on attitudinal dimensions: a review and synthesis." Academy of Management Review 10(3): 435-54.

Salomon, R., and Wu, Z. 2012. "Institutional distance and local isomorphism strategy.” Journal of International Business Studies 43: 343-367.

Singh, R.P. 2000. Entrepreneurial Opportunity Recognition Through Social Networks. New York: Garland Publishing.

Slotte-Kock, S., and Coviello, N. 2010. "Entrepreneurship Research on Network Processes: A Review and Ways Forward." Entrepreneurship Theory and Practice 34(1) 31-57.

Svendsen, G.H. 2006. "Studying social capital in situ: A qualitative approach.” Theory and Society 35(1): 39-70. 
Szymanski, D. 2000. Impact of National Cultures on Finnish-French Teamwork. Publications of Vaasa University: Vaasa.

Thornton, P. H., and Ocasio, W. 1999. "Institutional logics and the historical contingency of power in organizations: Executive succession in the higher education publishing industry, 1958-1990 1.” American journal of Sociology 105(3): 801-843.

Thornton, P. H., and Ocasio, W. 2008. Institutional logics. The Sage handbook of organizational institutionalism 840: 99-128.

Thornton, P. H., Ocasio, W., and Lounsbury, M. 2012. "The institutional logics perspective: A new approach to culture, structure, and process." Oxford University Press on Demand.

Toivanen, E. 2000. Kahden puolen kanaalin. Kustannusosakeyhtio Otava: Helsinki.j[epi]

Trompenaars, F., and Hampden-Turner, C. 1997. Riding the Waves of Culture: Understanding Cultural Diversity in Business. 2nd ed. Nicholas Brealey: Londonisêp:

Tsang, E.W.K. 2002. "Learning from overseas venturing experience: the case of Chinese businesses." Journal of Business Venturing 17(1): 21.

Welch, C., Piekkari, R., Plakoyiannaki, E., and Paavilainen-Mantymaki, E. 2011. "Theorising from case studies: Towards a pluralist future for international business research.” Journal of International Business Studies 42: 740-762.

Xu, D., and Shenkar, O. 2002. "Institutional distance and the multinational enterprise." Academy of Management Review 27(4): 608-618.

Yin, R.K. 1994. Case Study Research: Design and Methods. California: Sage.

Yli-Renko, H., Autio, E., and Tontti, V. 2002. "Social capital, knowledge, and the international growth of technology-based new firms.” International Business Review 11(3): 279-304. 
Table 1. Information on the case firms

Firm Number of Year of Start of Entry to France Industry segment employees establish- internation-

\begin{tabular}{|c|c|c|c|c|c|}
\hline Alpha & 30 & $\begin{array}{l}\text { ment } \\
1978\end{array}$ & $\begin{array}{l}\text { alization } \\
1980\end{array}$ & $\begin{array}{l}1990 \text { import } \\
1991 \text { export }\end{array}$ & $\begin{array}{l}\text { Fire } \\
\text { equipment }\end{array}$ \\
\hline Beta & 18 & 1923 & 1929 & 1968 export & Wooden toys \\
\hline Gamma & 200 & 1967 & 1979 & 1997 subsidiary & $\begin{array}{l}\text { Machines } \\
\text { forestry } \\
\text { agriculture }\end{array}$ \\
\hline Delta & 150 & 1955 & $1990 \mathrm{~s}$ & 1990s export & $\begin{array}{l}\text { Sauna stoves and } \\
\text { equipment }\end{array}$ \\
\hline Epsilon & 140 & 1972 & $1980 \mathrm{~s}$ & $\begin{array}{l}1989 \text { export } \\
2006 \text { production } \\
\text { subsidiary }\end{array}$ & Packaging material \\
\hline Zeta & 249 & 1876 & $1970 \mathrm{~s}$ & $\begin{array}{l}1982 \text { export } \\
1984 \text { subsidiary }\end{array}$ & Industrial furniture \\
\hline Eta & 40 & 1988 & 1991 & $\begin{array}{l}1991 \\
\text { production/sales } \\
\text { subsidiary }\end{array}$ & $\begin{array}{l}\text { Pipettes and } \\
\text { analyzing systems }\end{array}$ \\
\hline Theta & 20 & 1973 & $1990 \mathrm{~s}$ & $\begin{array}{l}1998 \text { export } \\
2002 \\
\text { representative }\end{array}$ & Log houses \\
\hline
\end{tabular}

Table 2. Sources of data.

\begin{tabular}{|l|l|l|l|l|l|l|l|l|}
\hline Firm & Interviews & $\begin{array}{l}\text { Domestic } \\
\text { informants }\end{array}$ & $\begin{array}{l}\text { Foreign } \\
\text { informants }\end{array}$ & Web pages & $\begin{array}{l}\text { Annual } \\
\text { reports }\end{array}$ & $\begin{array}{l}\text { Financial } \\
\text { records }\end{array}$ & $\begin{array}{l}\text { Minutes of } \\
\text { meetings }\end{array}$ & Brochures \\
\hline Alpha & 2 & 2 & 0 & $\mathrm{X}$ & & & & $\mathrm{X}$ \\
\hline Beta & 2 & 2 & 0 & $\mathrm{X}$ & $\mathrm{X}$ & $\mathrm{X}$ & & $\mathrm{X}$ \\
\hline Gamma & 3 & 2 & 1 & $\mathrm{X}$ & $\mathrm{X}$ & & & $\mathrm{X}$ \\
\hline Delta & 2 & 2 & 0 & $\mathrm{X}$ & $\mathrm{X}$ & & & $\mathrm{X}$ \\
\hline Epsilon & 2 & 2 & 0 & $\mathrm{X}$ & $\mathrm{X}$ & $\mathrm{X}$ & & $\mathrm{X}$ \\
\hline Zeta & 3 & 2 & 1 & $\mathrm{X}$ & $\mathrm{X}$ & $\mathrm{X}$ & & $\mathrm{X}$ \\
\hline Eta & 6 & 4 & 1 & $\mathrm{X}$ & $\mathrm{X}$ & $\mathrm{X}$ & $\mathrm{X}$ & $\mathrm{X}$ \\
\hline Theta & 2 & 1 & 1 & $\mathrm{X}$ & & & & $\mathrm{X}$ \\
\hline
\end{tabular}


Table 3. Analysis of data from the perspective of structural holes (SHs), network closure (NC), strength of network ties (NTS), and

\section{institutional distance.}

\begin{tabular}{|c|c|c|c|c|}
\hline Firm & Structural holes (SH) activity & Network closure (NC) activity & Strength of NTs & Institutional distance - problematic aspects \\
\hline Alpha & $\begin{array}{l}\text { SH activity - limited (for entry) } \\
\text { The importer relationship enabled } \\
\text { initial access to the French market } \\
(1990) \text {. Looked for and found a } \\
\text { French agent together with the } \\
\text { importer in } 1991 \text {. } \\
\text { No NTs have been added since } \\
\text { then. }\end{array}$ & $\begin{array}{l}\text { NC activity - medium } \\
\text { NC has been the main activity after } \\
\text { the initial entry, but the intensity } \\
\text { has been medium - they use } \\
\text { mainly emails, phone calls, and } \\
\text { meet only once a year, mainly in } \\
\text { France. }\end{array}$ & \begin{tabular}{ll}
\multicolumn{2}{l}{ Medium } \\
(even after 25 \\
years & of \\
exporting) &
\end{tabular} & $\begin{array}{l}\text { View of time } \\
\text { Communication } \\
\text { CEO of Alpha: "They pay when they pay. Often } \\
\text { after the deadline. But we have kind of got used } \\
\text { to it. Another thing is that we need to be in } \\
\text { touch with them frequently, because they like it } \\
\text { that way." }\end{array}$ \\
\hline Beta & $\begin{array}{l}\text { SH activity - limited (for entry) } \\
\text { Prior to first entry Beta attended } \\
\text { trade fairs in France; found a } \\
\text { suitable agent who "felt like a } \\
\text { good, trustworthy guy" in } 1968 \text {. } \\
\text { No NTs have been added since } \\
\text { then. }\end{array}$ & $\begin{array}{l}\text { NC activity - medium } \\
\mathrm{NC} \text { has been the main activity } \\
\text { since the initial entry, but the } \\
\text { intensity has been medium; the } \\
\text { firms communicate mainly via } \\
\text { emails and phone calls. Initially } \\
\text { Beta visited the exporter } \\
\text { personally twice a year. Currently } \\
\text { they meet once a year at trade fairs } \\
\text { in Europe. }\end{array}$ & \begin{tabular}{ll}
\multicolumn{2}{l}{ Medium } \\
(even after 40 \\
years & of \\
exporting) &
\end{tabular} & $\begin{array}{l}\text { Hierarchy } \\
\text { Communication } \\
\text { View of time } \\
\text { "We have understood over time that they have } \\
\text { more hierarchy, and we need to be stricter with } \\
\text { them. And to be in touch regularly to make } \\
\text { them write their reports and sell." }\end{array}$ \\
\hline Gamma & $\begin{array}{l}\text { SH activity - medium (for entry) } \\
\text { Contacted Finpro for expansion } \\
\text { purposes and thus found two } \\
\text { agents (a woman of Finnish origin } \\
\text { and a Belgian man); } \\
\text { simultaneously looked for and sent } \\
\text { a Finnish entrepreneur to France, } \\
\text { to work for one year promoting the } \\
\text { firm's forest machines. }\end{array}$ & $\begin{array}{l}\text { NC activity-medium } \\
\text { Initially had social interaction, but } \\
\text { only with the Belgian agent, and } \\
\text { the original Finnish subsidiary } \\
\text { manager felt quite alone: } \\
\text { "I feel I have no support at all. } \\
\text { They have left me totally alone, } \\
\text { without basically giving any } \\
\text { support at all. And then they just }\end{array}$ & $\begin{array}{l}\text { Medium-to-weak } \\
\text { With the existing } \\
\text { agent, the strength } \\
\text { has remained at a } \\
\text { medium level. } \\
\text { Due to limited } \\
\text { communication, } \\
\text { the relationship } \\
\text { with the other }\end{array}$ & $\begin{array}{l}\text { Legal differences } \\
\text { Social interaction } \\
\text { View of time } \\
\text { "We needed to hire a lawyer to really } \\
\text { understand how to establish a sales subsidiary } \\
\text { in France... They are often late with the } \\
\text { payments. It is just something you need to get } \\
\text { used to." }\end{array}$ \\
\hline
\end{tabular}




\begin{tabular}{|c|c|c|c|c|}
\hline & $\begin{array}{l}\text { Only the Belgian agent was still } \\
\text { operating at the time of the } \\
\text { interviews. }\end{array}$ & $\begin{array}{l}\text { said they wanted to close the } \\
\text { subsidiary for strategic reasons, } \\
\text { although I was doing a good job, } \\
\text { even without their support." }\end{array}$ & $\begin{array}{l}\text { agent was already } \\
\text { weakened prior to } \\
\text { closing down the } \\
\text { subsidiary. }\end{array}$ & \\
\hline Delta & $\begin{array}{l}\text { SH activity - strong (both for } \\
\text { entry and to expand) } \\
\text { Found the two original agents at } \\
\text { trade fairs in France in the 1990s. } \\
\text { New agents have been added to the } \\
\text { circle of agents (currently 7) in } \\
\text { regular intervals via trade fairs and } \\
\text { unsolicited agreements. }\end{array}$ & $\begin{array}{l}\text { NC activity - strong } \\
\text { Delta has been able to develop a } \\
\text { good level of trust with its agents, } \\
\text { coping skillfully with psychic } \\
\text { distance via its well-educated } \\
\text { employees. It has communicated } \\
\text { with them on an almost daily basis. } \\
\text { However, two agents withdrew } \\
\text { from cooperation during the } \\
\text { present century. }\end{array}$ & $\begin{array}{l}\text { Medium } \\
\text { (Weak NTs have } \\
\text { been terminated.) }\end{array}$ & Communication \\
\hline Epsilon & $\begin{array}{l}\text { SH activity - strong (for entry, } \\
\text { and especially to expand) } \\
\text { Initially found NTs for the French } \\
\text { market by attending trade fairs in } \\
\text { France; } \\
\text { active mainly initially, but still } \\
\text { adding new NTs; } \\
\text { in addition to replacing two of its } \\
\text { four agents with better ones, it has } \\
\text { sought suitable production } \\
\text { opportunities in France through } \\
\text { two intermediary organizations, } \\
\text { Invest in France and Finpro. A } \\
\text { suitable partner was found through } \\
\text { Invest in France, and a joint } \\
\text { venture involving a production } \\
\text { plant was established in 2006. }\end{array}$ & $\begin{array}{l}\text { NC activity - strong } \\
\text { The current CEO of Epsilon went } \\
\text { to live in France for a couple of } \\
\text { years, to strengthen the NTs prior } \\
\text { to taking over the firm from his } \\
\text { father. } \\
\text { Epsilon has communicated and } \\
\text { met regularly with both the joint } \\
\text { venture co-operators and the } \\
\text { agents. }\end{array}$ & $\begin{array}{l}\text { Strong ties with } \\
\text { joint venture } \\
\text { Medium ties with } \\
\text { agents } \\
\text { (NTs with weak } \\
\text { agents have been } \\
\text { terminated.) }\end{array}$ & $\begin{array}{l}\text { None } \\
\text { The CEO had lived in Europe before taking } \\
\text { over Epsilon and regards institutional } \\
\text { differences as almost insignificant. }\end{array}$ \\
\hline Zeta & $\begin{array}{l}\text { SH activity - limited (for entry) } \\
\text { Went to trade fairs in France and } \\
\text { found a "good guy" there }\end{array}$ & $\begin{array}{l}\text { NC activity - medium } \\
\text { Has tried to create a better level of } \\
\text { trust with people in the subsidiary; } \\
\text { however, communicates only on a } \\
\text { weekly basis, and visits once a year. } \\
\text { It has been difficult for Zeta to } \\
\text { allow the subsidiary manager to } \\
\text { make decisions. }\end{array}$ & $\begin{array}{l}\text { Weak-to- } \\
\text { medium } \\
\text { "We have had to } \\
\text { change a poor } \\
\text { subsidiary } \\
\text { manager three } \\
\text { times." }\end{array}$ & $\begin{array}{l}\text { Communication } \\
\text { Hierarchy } \\
\text { "We left them too much alone. They were } \\
\text { dancing on the tables and using the money for } \\
\text { the wrong purposes. They need hierarchical } \\
\text { management and a lot of contact. And they } \\
\text { have such a different temperament - it took } \\
\text { time to get used to them shouting on the phone } \\
\text { over very minor issues. It's just their style." }\end{array}$ \\
\hline
\end{tabular}




\begin{tabular}{|c|c|c|c|c|}
\hline Eta & $\begin{array}{l}\text { No SH activity } \\
\text { SH has never been the focus, due } \\
\text { to earlier strong ties. }\end{array}$ & $\begin{array}{l}\text { NC activity - strong } \\
\text { NC has been active throughout, in } \\
\text { order to maintain an excellent NC } \\
\text { position. }\end{array}$ & Strong & $\begin{array}{l}\text { None } \\
\text { The CEO had owned another enterprise for } 20 \\
\text { years, and still has the same subsidiary } \\
\text { manager. Since Eta has such a strong } \\
\text { relationship in France, it regards institutional } \\
\text { differences as almost insignificant. }\end{array}$ \\
\hline Theta & $\begin{array}{l}\text { SH activity - limited (after the } \\
\text { initial entry) } \\
\text { The initial NT, a Frenchman } \\
\text { living in Finland contacted Theta } \\
\text { in 1990; they then looked together } \\
\text { for a circle of retailers in France in } \\
\text { 1991-1992, but were } \\
\text { unsuccessful, and did not find any } \\
\text { retailers. } \\
\text { No new NTs have been added. }\end{array}$ & $\begin{array}{l}\text { NC activity - strong } \\
\text { Has been in intensive interaction } \\
\text { with the office manager of the } \\
\text { French representative since the } \\
\text { beginning. }\end{array}$ & $\begin{array}{l}\text { Strong } \\
\text { (Weak ties have } \\
\text { been terminated.) }\end{array}$ & $\begin{array}{l}\text { A different view of honesty } \\
\text { "They said they would now sell twenty log } \\
\text { houses, but they sold nothing at all. They were } \\
\text { so terribly untrustworthy. Promising things, } \\
\text { but then just letting us down. We actually gave } \\
\text { some initial sales support money to them, and } \\
\text { we lost all of it." }\end{array}$ \\
\hline
\end{tabular}

